Part of Journal of Research of the National Bureau of Standards, Volume 30, June 1943

\title{
THERMAL EXPANSIVITY AND DENSITY OF INDIUM
}

\author{
By Peter Hidnert and Mary Grace Blair
}

\section{ABSTRACT}

The linear thermal expansion of cast indium of high purity was investigated between $-190^{\circ}$ and $+100^{\circ} \mathrm{C}$ and the cubical thermal expansion between $0^{\circ}$ and $50^{\circ} \mathrm{C}$. The following equation was derived for the linear expansion of indium:

$$
L_{t}=L_{0}\left[1+\left(28.9_{3} t+0.013_{4} t^{2}\right) 10^{-6}\right],
$$

where $L_{0}$ represents the length of the metal at $0^{\circ} C$, and $L_{t}$ the length at any temperature, $t$, within the range of the observations. The average coefficients of cubical expansion of indium were found to be $77 \times 10^{-6}$ and $101 \times 10^{-6}$ per degree centigrade for the ranges $0^{\circ}$ to $25^{\circ} \mathrm{C}$ and $25^{\circ}$ to $50^{\circ} \mathrm{C}$, respectively. These coefficients of cubical expansion are not equal to three times the coefficients of linear expansion for the corresponding temperature ranges on account of the anisotropy of indium.

The density of cast indium was found to be $7.281 \mathrm{~g} / \mathrm{cm}^{3}$ at $22.6^{\circ} \mathrm{C}$. The density of indium calculated from the best available data on atomic weights and lattice constants is $7.4 \mathrm{~g} / \mathrm{cm}^{3}$. Observed densities at $0^{\circ}, 25^{\circ}$, and $50^{\circ} \mathrm{C}$ are also given in this paper.

$$
\text { 7. } 34
$$

\section{CONTENTS}

I. Introduction

II. Material investigated

III. Apparatus_.

IV. Results

1. Thermal expansion

2. Density

V. References_...

\section{INTRODUCTION}

In 1869 Fizeau [1] ${ }^{1}$ reported the value $41.7 \times 10^{-6}$ per degree centigrade for the coefficient of linear thermal expansion of cast indium at $40^{\circ} \mathrm{C}$ and the value $0.4238 \times 10^{-6}$ as the change per degree centigrade in the coefficient, or rate, of expansion. He computed the value $45.9 \times 10^{-6}$ per degree centigrade for the average coefficient of expansion of indium between $0^{\circ}$ and $100^{\circ} \mathrm{C}$. The work described in the present paper was undertaken in order to obtain data on the linear thermal expansion of high-purity indium over a wide range of temperature $\left(-190^{\circ}\right.$ to $\left.+100^{\circ} \mathrm{C}\right)$. Data on the cubical thermal expansion and density of indium between $0^{\circ}$ and $50^{\circ} \mathrm{C}$ were also obtained.

Industrial applications of indium have been indicated by Murray [2], Williams [3], Linford [4], Dyer [5], and Ludwick [6]. A compilation of some of the physical properties of indium was given by Westbrook [7].

\footnotetext{
1 Figures in brackets indicate the literature references at the end of this paper,
} 


\section{MATERIAL INVESTIGATED}

A rod of cast indium loaned to the National Bureau of Standards by the Indium Corporation of America, Utica, N. Y., was used for the determinations of thermal expansion and density. A spectrochemical analysis ${ }^{2}$ was made on a piece cut from the rod of indium. Traces of $\mathrm{Ag}, \mathrm{Ca}, \mathrm{Cr}, \mathrm{Mg}$, and $\mathrm{Tl}$, small amounts (less than 0.01 percent) of $\mathrm{Al}, \mathrm{Cd}(?), \mathrm{Co}(?), \mathrm{Cu}, \mathrm{Mn}, \mathrm{Si}$, and $\mathrm{Sn}$, and larger amounts of $\mathrm{Fe}, \mathrm{Ni}$, and $\mathrm{Pb}$, were reported. The results of a chemical analysis ${ }^{3}$ were: Fe, 0.01 percent; $\mathrm{Pb}, 0.01$ percent; and $\mathrm{Ni}$, not detected. The indium content was estimated to be 99.9 percent.

X-ray diffraction patterns ${ }^{4}$ obtained on a piece cut from the rod of indium, after the second expansion test had been completed, indicated large crystals. A subsequent examination (see footnote 4) of an etched section of the piece of indium indicated that the average diameter of the crystals was 1 to $2 \mathrm{~mm}$.

\section{APPARATUS}

Five linear expansion tests were made on the rod of indium $(10 \mathrm{~mm}$ in diam). The length of the sample was $250 \mathrm{~mm}$ for tests 1 and 2 , which were made from $20^{\circ}$ to $100^{\circ} \mathrm{C}$ with the precision micrometric thermal-expansion apparatus described by Souder and Hidnert [8]. The details of the specimen mounting for use in the furnace are illustrated in figure 4 of their publication.

Tests $3^{5}$ to 5 were made at low temperatures with the fusedquartz-tube thermal-expansion apparatus ${ }^{6}$ described by Hidnert and Sweeney [9]. Liquid air, solid carbon dioxide in a mixture of equal parts of carbon tetrachloride and chloroform, and ice and water were used for low temperature baths at about $-190^{\circ},-78^{\circ}$, and $0^{\circ} \mathrm{C}$, respectively.

\section{RESULTS}

\section{THERMAL EXPANSION}

Figures 1 and 2 show the linear expansion and contraction curves of the sample of indium on two cycles of heating and cooling between $20^{\circ}$ and $100^{\circ} \mathrm{C}$ and on three cycles of cooling and heating at low temperatures. Table 1 gives the coefficients of expansion and contraction obtained from these curves.

\footnotetext{
2 By Dorothy Grosch, of the National Bureau of Standards.

3 By R. K. Bell, of the National Bureau of Standards.

1 By H. C. Vacher, of the National Bureau of Standards.

3 Before test 3 , the rod of indium was cut to a length of $200 \mathrm{~mm}$.

o This apparatus was found to be unsatisfactory for determinations of the linear thermal expansion of indium above room temperature on account of flow of the sample caused by the combined weight of the foot of the dial indicator and the movable fused-quartz rod of the apparatus.
} 


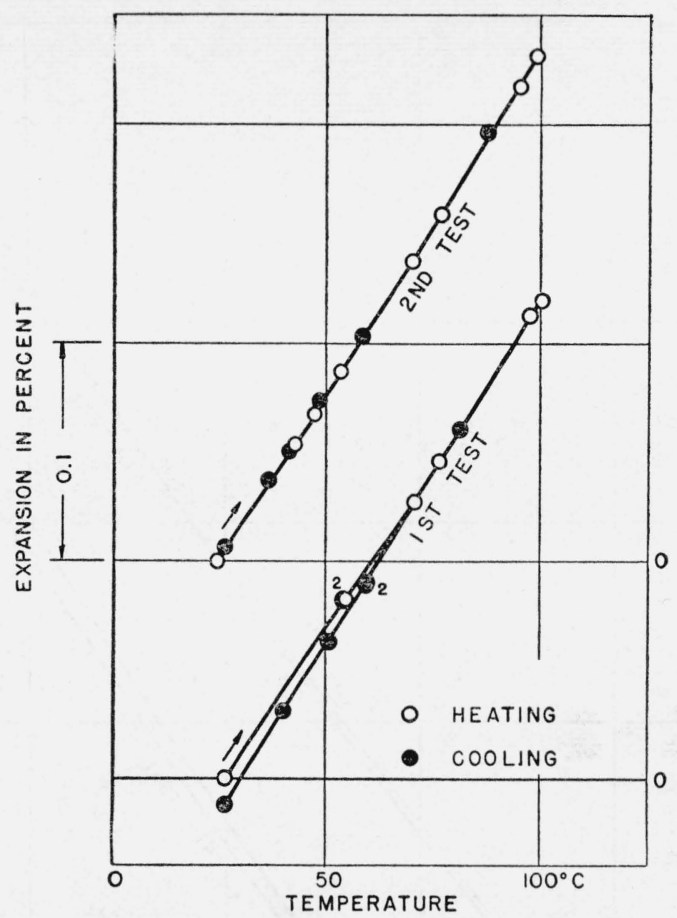

FIGURE 1.-Linear thermal expansion of indium on heating from room tem perature to $100^{\circ} \mathrm{C}$ and contraction on subsequent cooling from $100^{\circ} \mathrm{C}$ to room temperature.

Each number adjacent to a point on the curve represents the number of observations at the temperature. The variations in these observations were too small to be indicated on this scale.

TABLE 1.-Coefficients of linear expansion and contraction of a sample of indium

\begin{tabular}{|c|c|c|c|c|c|c|c|}
\hline \multirow[b]{2}{*}{ Test } & \multirow[b]{2}{*}{ Treatment a } & \multicolumn{6}{|c|}{$\begin{array}{l}\text { A verage coefficients of expansion and con- } \\
\text { traction per degree centigrade }\end{array}$} \\
\hline & & to $\frac{-190^{\circ}}{\mathrm{C}}$ & $-80^{\circ} \mathrm{C}$ & $\begin{array}{l}-80^{\circ} \text { to } \\
+20^{\circ} \mathrm{C}\end{array}$ & $\begin{array}{l}20^{\circ} \text { to } \\
60^{\circ} \mathrm{C}\end{array}$ & $\begin{array}{l}60^{\circ} \text { to } \\
100^{\circ} \mathrm{C}\end{array}$ & $\begin{array}{r}20^{\circ} \text { to } \\
100^{\circ} \mathrm{C}\end{array}$ \\
\hline & & $\times 10^{-6}$ & $\times 10^{-6}$ & $\times 10^{-6}$ & $\left\{\begin{array}{r}\times 10^{-6} \\
29.0\end{array}\right.$ & $\begin{array}{r}\times 10^{-6} \\
30.3\end{array}$ & $\begin{array}{r}\times 10^{-6} \\
29.7\end{array}$ \\
\hline 1 \{ Cooling-- & As cast & & & & 30.5 & 31.6 & 31.0 \\
\hline $2\left\{\begin{array}{l}\text { Heating } \\
\text { Cooling }-\end{array}\right.$ & Heated to $100^{\circ} \mathrm{C}$ and cooled slowly. & & & & $\left\{\begin{array}{l}29.8 \\
30.2\end{array}\right.$ & $\begin{array}{l}31.4 \\
31.2\end{array}$ & $\begin{array}{l}30.6 \\
30.7\end{array}$ \\
\hline 3, Cooling -- & Reheated to $100^{\circ} \mathrm{C}$ and cooled slowly ... & & 28. 2 & 28.4 & $\left(\begin{array}{ccc}c & 00.2\end{array}\right.$ & & -... \\
\hline $4\left\{\begin{array}{l}\text { Cooling } \\
\text { Heating - }\end{array}\right.$ & Cooled to $-80^{\circ} \mathrm{C}$ and heated to $+20^{\circ} \mathrm{C}$. & $\begin{array}{l}25.6 \\
24.8\end{array}$ & $\begin{array}{l}29.1 \\
28.0\end{array}$ & 28.1 & & & \\
\hline $5\left\{\begin{array}{l}\text { Cooling } \\
\text { Heating - }\end{array}\right.$ & Cooled to $-190^{\circ} \mathrm{C}$ and heated to $+20^{\circ} \mathrm{C}$. & $\begin{array}{l}25.1 \\
25.4\end{array}$ & $\begin{array}{l}28.2 \\
26.9\end{array}$ & $\begin{array}{l}28.5 \\
27.1\end{array}$ & 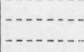 & & \\
\hline Values from & equation 2 & 25.3 & 27.9 & 28.1 & 30.0 & 31.1 & 30.5 \\
\hline
\end{tabular}

- All heat treatments on the cast sample were incident to the tests on thermal expansion. 


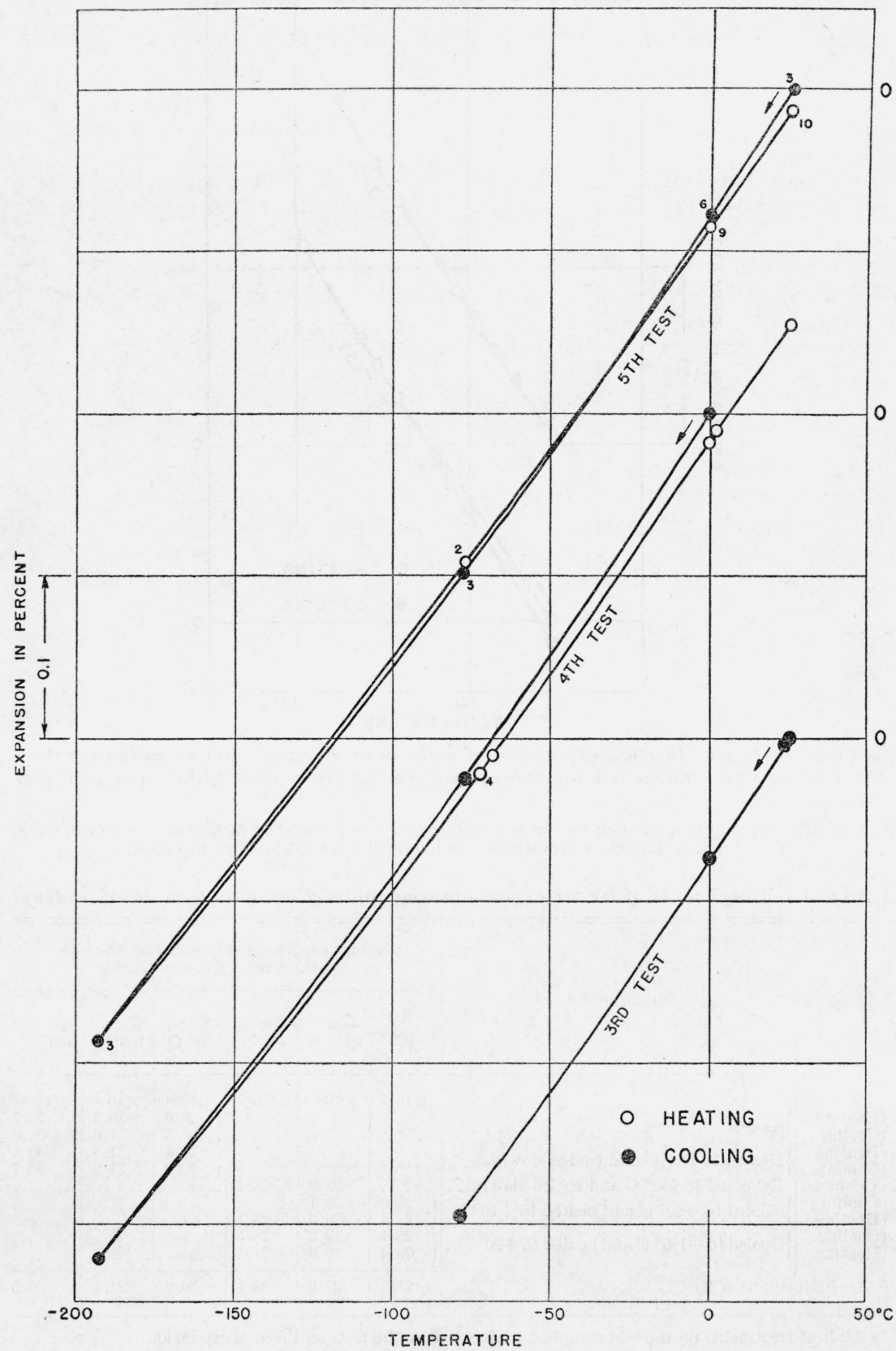

Figure 2.-Linear thermal contraction on cooling to low temperatures and expansion on subsequent heating to room temperature.

Each number adjacent to a point on the curve represents the number of observations at the temperature. The variations in these observations were too small to be indicated on this scale. 
From the average coefficients of linear expansion and contraction obtained in the five tests on indium (table 1), the following linear equation was derived by the method of least squares:

$$
a_{t}=\left(28.9_{3}+0.026_{8} t\right) 10^{-6},
$$

where $a_{t}$ is the instantaneous coefficient of expansion (contraction) or the rate of expansion (contraction) at any temperature, $t^{\circ} \mathrm{C}$, between $-135^{\circ}$ and $+80^{\circ} \mathrm{C}$. The probable error of $a_{t}$ is $\pm 0.4 \times 10^{-6}$. The differences in the coefficients of expansion (table 1) and the magnitude of the probable error of $a_{t}$ indicate that this metal failed to give reproducible results on heating and cooling.

The following second-degree equation was obtained by integration of equation 1 :

$$
L_{t}=L_{0}\left[1+\left(28.9_{3} t+0.013_{4} t^{2}\right) 10^{-6}\right] .
$$

In this equation, $L_{0}$ represents the length at $0^{\circ} \mathrm{C}$ and $L_{t}$ the length at any temperature, $t^{\circ} \mathrm{C}$, within the range of the observations.

After the determinations on linear thermal expansion had been completed, the cubical expansion of the sample of indium was determined between $0^{\circ}$ and $50^{\circ} \mathrm{C}$ by weighing the sample in air at room temperature and in water at $0^{\circ}, 25^{\circ}$, and $50^{\circ} \mathrm{C}$. Table 2 gives the coefficients of cubical expansion. These coefficients of cubical expansions ${ }^{7}$ are not equal to three times the coefficients of linear expansion of the sample of indium on account of the anisotropy ${ }^{8}$ of indium.

\begin{tabular}{|c|c|}
\hline $\begin{array}{l}\text { Temperature } \\
\text { range }\end{array}$ & $\begin{array}{l}\text { Average } \\
\text { coefficient } \\
\text { of cubical } \\
\text { expansion } \\
\text { per degree } \\
\text { centigrade }\end{array}$ \\
\hline $\begin{array}{r}\quad{ }^{\circ} \mathrm{C} \\
0 \text { to } 25 \\
25 \text { to } 50 \\
0 \text { to } 50 \ldots\end{array}$ & $\begin{array}{c}\times 10^{-6} \\
77 \\
101 \\
89\end{array}$ \\
\hline
\end{tabular}

TABLE 2.-Coefficients of cubical expansion of indium

The coefficient of linear expansion of indium $\left(30.0 \times 10^{-6}\right)$ at $40^{\circ} \mathrm{C}$, computed from equation 1 , is considerably less than the coefficient $41.7 \times 10^{-6}$ reported by Fizeau [1]. The large divergence between these values may be ascribed to different orientations of the crystals in the two samples.

Frevel and Ott [10] determined the coefficients of linear thermal expansion of crystal indium along the $a$-axis and the $c$-axis from $\mathrm{X}$-ray measurements on the cell dimensions of 99.9-percent-pure indium. They reported $56 \times 10^{-6}$ and $13 \times 10^{-6}$ for the coefficients of linear expansion along the $a$-axis and $c$-axis, respectively, for the range ${ }^{9}$ from $-17^{\circ}$ to $+9^{\circ}$ C. From these coefficients of linear

\footnotetext{
7 Except the coefficient of cubical expansion for the range $0^{\circ}$ to $50^{\circ} \mathrm{C}$.

- Crystal structure of indium is face-centered tetragonal [10, 11].

This range of temperature was reported in a private communication by L. K. Frevel, The Dow Chemical Co., Midland, Mich.
} 
expansion, the computed coefficient of cubical expansion is $125 \times 10^{-6}$ for the range from $-17^{\circ}$ to $+9^{\circ} \mathrm{C}$. The coefficients of cubical expansion given in table 2 are less than the value calculated from the results of Frevel and Ott [10] at a lower range of temperature.

\section{DENSITY}

Before the determinations of thermal expansion were made, the density of the $250-\mathrm{mm}$ rod of indium was found to be $7.281 \mathrm{~g} / \mathrm{cm}^{3}$ at $22.6^{\circ} \mathrm{C}$. The density of indium was also calculated from the equation

$$
D=\frac{n w\left(1 / N_{0}\right)}{a^{2} c}
$$
Where $D$ is the density $n$ is the number of atoms the atomic weight of the metal, No is the Avogadr number, and $a$ and $c$ are the lattice gonstants of the metal. If the following values are substituted in this equation:

$$
\begin{aligned}
& n=4, \quad w=1.14 .76, \quad N_{O}=6.023 \times 10^{23}, \\
& a=4.585 \times 10^{-8} \mathrm{~cm}, c=4.941 \times 10^{-8} \mathrm{~cm},
\end{aligned}
$$

the computed aensity is $7.337 \mathrm{~g} / \mathrm{cm} 3$. This value agrees within 1 percent of the opserved density observed densities reported in thezIterature 14 range from about 7 . I2 to $7.42 \mathrm{~g} / \mathrm{cm}$.

$$
\text { (In footrote 10, delete "H and") }
$$

After the completion of the thermal-expansion determinations, the density of the $200-\mathrm{mm}$ rod of indium was calculated at several temperatures from the data obtained in the determinations of cubical expansion. The results are given in table 3 .

TABLE 3.--Density of indium

\begin{tabular}{|c|c|}
\hline Temperature & Density \\
\hline${ }^{\circ} \mathrm{C}$ & $\mathrm{g} / \mathrm{cm}^{3}$ \\
25 & 7.275 \\
0 & 7.289 \\
50 & 7.257 \\
25 & 7.274 \\
\hline
\end{tabular}

\section{REFERENCES}

[1] H. Fizeau, Tableau des dilatations par la chaleur de divers corps simples métal liques ou non métalliques, et de quelques composés hydrogénés du carbone, Compt. rend. 68, 1125 (1869) or Wärme-Ausdehnungen verschiedener einfacher, metallischer und nicht-metallischer Körper, so wie einiger Kohlenwasserstoff-Verbindungen, Ann. Physik u. Chem. 18, [5] (138), 26 (1869).

[2] W. S. Murray, Indium available in commercial quantities, Ind. Eng. Chem. 24, 686 (1932)

[3] R. V. Williams, Use of indium in dental alloys, J. Am. Coll. Dentists 5, 78 (1938).

[4] H. B. Linford, Indium, Chem. \& Chem. Eng., News Ed. 18, 624 (1940).

10 Values for $H$ and $N_{0}$ complied by Birge [12] and those for $a$ and $c$ by Neuburger [13]. 
[5] J. R. Dyer, Jr., Indium, Iron Age 146, 35 (Dec. 19, 1940).

[6] M. T. Ludwick, Indium, Steel 111, 80 (Nov. 9, 1942).

[7] L. R. Westbrook, Indium: Recovery by electrodeposition, Trans. Am. Electrochem. Soc. 5\%, 289 (1930).

[8] W. Souder and P. Hidnert, Measurements on the thermal expansion of fused silica, Sci. Pap. BS 21, 1 (1926-27) S524.

[9] P. Hidnert and W. T. Sweeney, Thermal expansion of magnesium and some of its alloys, BS J. Research 1, 771 (1928) RP29.

[10] L. K. Frevel and E. Ott, The X-ray study of indium and the indium-silver system, J. Am. Chem. Soc. 5\%, 228 (1935).

[11] E. Zintl and S. Neumayr, Gitterstruktur des Indiums, Z. Elektrochem. 39, 81 (1933).

[12] R. T. Birge, A new table of values of the general physical constants, Rev. Modern Phys. 13, 233 (1941).

[13] M. C. Neuburger, Gitterkonstanten für das Jahr 1936, Z. Krist. 93, 1 (1936).

[14] J. W. Mellor, A Comprehensive Treatise on Inorganic and theoretical Chemistry 5, 390 (Longman, Green, \& Co., London and New York, 1924).

WAshington, January 21, 1943. 